\title{
Interstitial fluid: the overlooked component of the tumor microenvironment?
}

\author{
Helge Wiig ${ }^{1,2^{*}}$, Olav Tenstad ${ }^{1}$, Per Ole Iversen ${ }^{3}$, Raghu Kalluri², Rolf Bjerkvig ${ }^{1}$
}

\begin{abstract}
Background: The interstitium, situated between the blood and lymph vessels and the cells, consists of a solid or matrix phase and a fluid phase, together constituting the tissue microenvironment. Here we focus on the interstitial fluid phase of tumors, i.e., the fluid bathing the tumor and stromal cells. Novel knowledge on this compartment may provide important insight into how tumors develop and how they respond to therapy.

Results: We discuss available techniques for interstitial fluid isolation and implications of recent findings with respect to transcapillary fluid balance and uptake of macromolecular therapeutic agents. By the development of new methods it is emerging that local gradients exist in signaling substances from neoplastic tissue to plasma. Such gradients may provide new insight into the biology of tumors and mechanistic aspects linked to therapy. The emergence of sensitive proteomic technologies has made the interstitial fluid compartment in general and that of tumors in particular a highly valuable source for tissue-specific proteins that may serve as biomarker candidates. Potential biomarkers will appear locally at high concentrations in the tissue of interest and will eventually appear in the plasma, where they are diluted.

Conclusions: Access to fluid that reliably reflects the local microenvironment enables us to identify substances that can be used in early detection and monitoring of disease.
\end{abstract}

\section{Introduction}

The interstitial space consists of connective and supporting tissues of the body and is located outside the blood and lymphatic vessels and parenchymal cells. Essentially the interstitium can be divided into two compartments: the interstitial fluid and the structural molecules of the interstitial or the extracellular matrix (ECM). In the present review we focus on the interstitial fluid phase, which contains an array of regulatory molecules defining the physical and biochemical microenvironment of cells. All organs have an interstitium, although at a variable amount. The structure and composition of the interstitium differs considerably depending on the mother organ. Interstitial water with its solutes, the interstitial fluid volume, serves as a transport medium for nutrients and waste products between cells and capillary blood and also harbors various signaling substances that are either produced locally or brought to the organ by the circulation.

\footnotetext{
* Correspondence: helge.wiig@biomed.uib.no

'Department of Biomedicine, University of Bergen, Bergen, Norway
}

Recently there has been a renewed interest in the tumor microenvironment because of its role in tumor growth and metastasis. The tumor microenvironment can be defined as the insoluble elements of the ECM, the stroma with its cellular elements such as fibroblasts and immune cells and the fluid phase of dissolved substances. Traditionally the focus has been on the stroma and the cellular elements of the tumor, whereas here we focus on the fluid phase that may be thought of as a "misconsidered component of the internal milieu of a solid tumor" [1].

We discuss recent data on the isolation of interstitial fluid and what can be learned from analyses of such fluid regarding local production of signaling substances and potential biomarkers as well as the level of interstitial fluid colloid osmotic pressure, one of the determinants of transcapillary fluid exchange. For a broader description of the latter topic, the reader is referred to reviews on transcapillary fluid exchange and interstitial fluid volume regulation [2-9]. The composition and structure of the interstitium has been the topic of 
several extensive reviews [10-15], and accordingly this topic is not discussed here.

\section{The tumor interstitium}

Although the tumor interstitium consists of the same components as the interstitia of normal tissues, i.e., an extracellular or interstitial matrix composed of solid elements constituting the framework of the tumor and a fluid phase constituting the interstitial fluid; it has its special features that are discussed briefly here. Before we turn to the interstitial/extracellular fluid phase, we summarize some common features of the ECM or solid phase in tumors compared to normal interstitium, as schematized in Figure 1. We do not discuss the properties of the tumor stroma, which has been the topic of several extensive recent reviews [16-22]. As stated by Kalluri and Zeisberg [18], there is considerable interest in understanding the differences between a normal stroma and a reactive tumor stroma. The normal stroma in most organs contains a minimal number of fibroblasts, whereas a reactive stroma is associated with an increased number of fibroblasts, enhanced capillary density, and type I collagen and fibrin deposition. A key factor in the formation of the reactive stroma is the vascular endothelial growth factor (VEGF) [23], either released by the cancer cells themselves or by fibroblasts, or inflammatory cells [24]. Increased levels of VEGF results in a high microvascular permeability that causes extravasation of plasma proteins such as fibrin, which in turn attract an influx of fibroblasts, inflammatory cells and endothelial cells $[25,26]$. The resulting reaction has similarities to wound healing where the cells produce an ECM rich in fibronectin and type I collagen and thus influence the composition of the stroma but also contribute to the process of initiating tumor angiogenesis $[26,27]$. Compared with non-neoplastic tissue, the tumor stroma contains increased amounts of collagens, proteoglycans and glycosaminoglycans, especially hyaluronan and chrondroitin sulfate, [e.g., [28-30]], as reviewed in [31]. These cellular responses are parallel to wound healing; the difference is that the generation of tumor stroma may be considered dysregulated wound healing [27].

\section{Tumor interstitial fluid}

The abnormal interstitium representing the microenvironment of the tumor cells has puzzled researchers for many years and continues to do so. Recently, an increased interest in the tumor microenvironment and its influence on cancer progression has turned attention toward this compartment (e.g., [18,19,22,32-34]). One may therefore envisage that access to tumor interstitial fluid (TIF), i.e., the fluid bathing the tumor and stroma cells, is of considerable importance to understand how tumors develop and progress. The properties of the tumor interstitium, e.g., the high vascularity and cellularity, represent major challenges when trying to gain access to the TIF.

\section{Methods of fluid isolation}

To quantify one of the determinants of the transcapillary fluid balance, the interstitial fluid protein concentration, and thus interstitial fluid colloid osmotic pressure as well as the tissue fluid concentration of signaling substances and molecules that may reflect local cellular processes, it is imperative to have the appropriate methodologies that provide reliable and representative native interstitial fluid.

In tumors, there is no uniform agreement as to which method to use to isolate TIF. As discussed above, lymph has been generally accepted as a measure of interstitial fluid [3]. Although many studies have shown that lymph vessels are present in tumor tissue (for review, see [35-38]), these vessels appear to be nonfunctional, i.e., not draining any fluid, at least in central tumor areas [37,39]. In addition, tumor lymphatics may not be cannulated, making lymph sampling inapplicable in this tissue, showing the need for alternative methods in tumors. We therefore discuss the available methods and their strengths and weaknesses from a tumor point of view (summarized in Table 1) before we turn to a discussion on recent data on composition of the interstitial fluid.

\section{Glass capillaries}

The glass capillary method for TIF isolation was described by Sylven and Bois [40]. They noted that the tumor periphery was rich in edema-like interstitial fluid, and isolated such fluid by inserting capillaries, 0.1-0.6 $\mathrm{mm}$ in diameter, into pouches made by blunt dissection in and along the periphery of the tumor or into sectioned tumor surface. The sampling procedure did not allow exact localization of the site of origin of the fluid, and Sylven and Bois acknowledged that it was possible that normal tissue fluid could also be included. Another obvious problem is an inherent tendency for cellular and vascular leakage that is likely to occur during sampling. The isolated fluid contained very high levels of intracellular enzymes, which indicates that the fluid isolated this way is a mixture of interstitial and intracellular fluid.

\section{Implantable chambers}

Much of our knowledge on TIF derives from experiments performed by Gullino et al. [41] in rats bearing various tumors using implantable chambers. The chambers were either inserted into a growing tumor or enclosed in it by allowing a tumor to grow around the chamber. The chamber was separated from tumor tissue by a porous membrane. Fluid draining into the chamber 


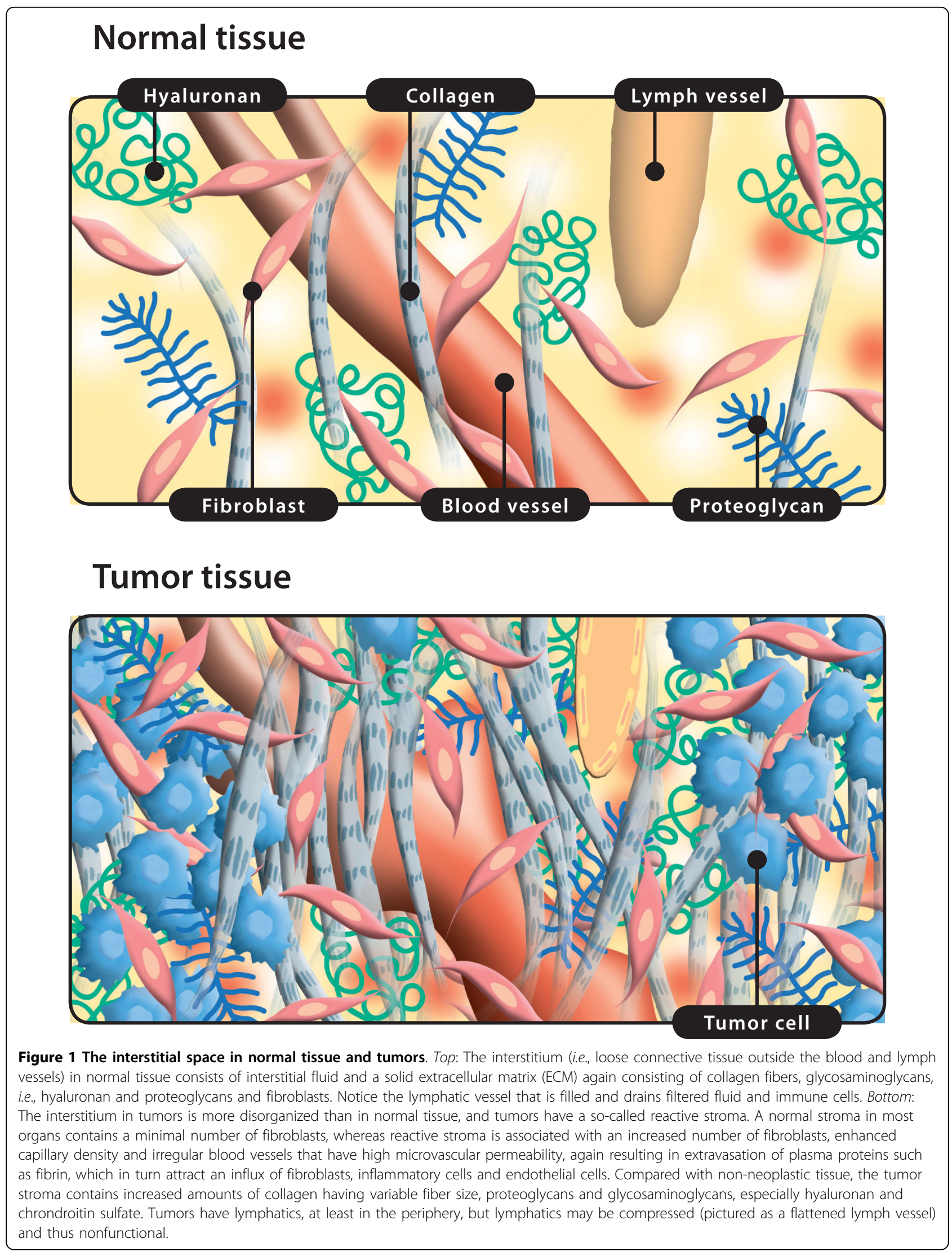


Table 1 Methods for tumor interstitial fluid isolation

\begin{tabular}{|c|c|c|c|c|c|c|}
\hline Method & How performed & What was sampled & Advantages & Disadvantages & Remarks & References \\
\hline $\begin{array}{l}\text { Glass } \\
\text { capillaries }\end{array}$ & $\begin{array}{l}\text { Insertion by blunt } \\
\text { dissection in vivo }\end{array}$ & $\begin{array}{l}\text { Fluid from tumor } \\
\text { periphery or sectioned } \\
\text { surface }\end{array}$ & In vivo native fluid & $\begin{array}{l}\text { Bleeding and } \\
\text { inflammation, } \\
\text { cellular disruption }\end{array}$ & $\begin{array}{l}\text { High level of } \\
\text { intracellular enzymes } \\
\text { in isolated fluid }\end{array}$ & {$[40]$} \\
\hline $\begin{array}{l}\text { Implantable } \\
\text { chambers }\end{array}$ & Chronically implanted & $\begin{array}{l}\text { Fluid draining from } \\
\text { central part of tumor }\end{array}$ & $\begin{array}{l}\text { In vivo native fluid, } \\
\text { continuous and } \\
\text { repeated sampling }\end{array}$ & $\begin{array}{l}\text { Inflammation in } \\
\text { early phases, scar } \\
\text { formation }\end{array}$ & $\begin{array}{l}\text { Requires chronic } \\
\text { restraining of animal }\end{array}$ & {$[41]$} \\
\hline $\begin{array}{l}\text { Implanted } \\
\text { wicks }\end{array}$ & $\begin{array}{l}\text { Implanted acutely or } \\
\text { chronically }\end{array}$ & $\begin{array}{l}\text { Fluid absorbed into } \\
\text { wicks during } \\
\text { implantation }\end{array}$ & In vivo, native fluid & $\begin{array}{l}\text { Bleeding and } \\
\text { inflammation, } \\
\text { cellular disruption }\end{array}$ & $\begin{array}{l}\text { Chronic implantation } \\
\text { more representative } \\
\text { than acute }\end{array}$ & {$[43]$} \\
\hline Microdialysis & $\begin{array}{l}\text { Insertion of } \\
\text { semipermeable } \\
\text { membrane }\end{array}$ & $\begin{array}{l}\text { Substances diffusing } \\
\text { across membrane }\end{array}$ & $\begin{array}{l}\text { In vivo continuous and } \\
\text { repeated sampling }\end{array}$ & $\begin{array}{l}\text { Inflammation, } \\
\text { incomplete } \\
\text { recovery, dilute } \\
\text { fluid }\end{array}$ & $\begin{array}{l}\text { Recovery especially } \\
\text { low for } \\
\text { macromolecules }\end{array}$ & $\begin{array}{l}\text { Reviewed } \\
\text { in [45] }\end{array}$ \\
\hline $\begin{array}{l}\text { Capillary } \\
\text { ultrafiltration }\end{array}$ & $\begin{array}{l}\text { Negative pressure } \\
\text { applied to } \\
\text { semipermeable } \\
\text { membrane }\end{array}$ & $\begin{array}{l}\text { Substances transported } \\
\text { by bulk flow across } \\
\text { membrane }\end{array}$ & $\begin{array}{l}\text { In vivo continuous and } \\
\text { repeated sampling }\end{array}$ & $\begin{array}{l}\text { Inflammation, } \\
\text { incomplete } \\
\text { recovery }\end{array}$ & $\begin{array}{l}\text { Recovery especially } \\
\text { low for } \\
\text { macromolecules }\end{array}$ & {$[60]$} \\
\hline $\begin{array}{l}\text { Tissue } \\
\text { centrifugation }\end{array}$ & $\begin{array}{l}\text { Exposure of excised } \\
\text { tissue to increased G- } \\
\text { force }\end{array}$ & $\begin{array}{l}\text { Fluid from tumor } \\
\text { periphery or bone } \\
\text { marrow }\end{array}$ & Native fluid & $\begin{array}{l}\text { Ex vivo single } \\
\text { samples }\end{array}$ & $\begin{array}{l}\text { Composition validated } \\
\text { by extracellular tracers }\end{array}$ & {$[61,77]$} \\
\hline Tissue elution & $\begin{array}{l}\text { Elution of minced } \\
\text { tissue }\end{array}$ & $\begin{array}{l}\text { Substances dissolved } \\
\text { in elution buffer }\end{array}$ & Technically easy & $\begin{array}{l}\text { Ex vivo single } \\
\text { samples, dilute fluid }\end{array}$ & $\begin{array}{l}\text { Contamination by } \\
\text { intracellular proteins } \\
\text { likely }\end{array}$ & {$[67]$} \\
\hline
\end{tabular}

could be collected by a catheter draining the cavity. After a period, necrosis developed and some hemorrhages appeared, but there was a definite interval when the chamber was enclosed by neoplastic cells and a low amount of necrosis that was used for fluid sampling. A main advantage with this approach is that fluid can be harvested for longer periods, e.g., to follow effects of therapy. Many of the potential problems with the method have been discussed by Jain [42]. One obvious issue is the inflammatory reaction and subsequent scarring that is induced by chamber insertion.

\section{Implanted wicks}

As for skin and muscle (for review, see [3]), wicks have been implanted in various types of solid tumors in mice to isolate interstitial fluid. Stohrer et al. [43] implanted saline-soaked wicks directly into established tumors (termed acute wicks) or simultaneously with tumor implantation (termed chronic wicks) and characterized the isolated fluid. In addition to evaluating the effect of acute and chronic insertion, they evaluated the effect of both implantation time and tumor type. They concluded that acute wick implantation requires a long time for equilibration (i.e., $>120 \mathrm{~min}$ ) and that chronic wicks should be preferred to avoid bleeding and cellular damage. Furthermore, as pointed out by Stohrer et al., cellular proteins deriving from necrotic cells or cells disrupted during wick removal may enter the wick fluid and cause a higher protein concentration (and higher colloid osmotic pressure). As a result, the protein distribution pattern will deviate from that of undisturbed tumor interstitial fluid, i.e., mainly proteins with lower molecular weight (MW) than albumin, e.g., as observed in skeletal muscle [44].

\section{Microdialysis}

The microdialysis technique, based on diffusion of analytes across a semipermeable membrane, has been applied extensively to study TIF (for reviews, see [45-52]). With this technique it is possible to sample endogenous and exogenous substances from the extracellular space, mainly small molecular species. At present, there has been an increased interest in using the technique in pharmacokinetic and pharmacodynamic studies [48,49,53], but it has also been applied to study peptides and proteins dissolved in the interstitial fluid (for recent reviews see, e.g., $[54,55]$ ). In such a context the major problems with the method is incomplete recovery of substances and also the potential inflammatory reactions resulting from insertion of the probe, and as pointed out by Clough [55], it is therefore unlikely that the dialysate reflects a representative concentration of the interstitial fluid.

\section{Capillary ultrafiltration}

Ultrafiltration has traditionally been used for separation or purification of chemicals, but this technique has also been applied to sample tissue fluid by implanting capillary ultrafiltration probes in vivo (reviewed in [56]). With this method fluid is sampled using negative pressure as a driving force, and the restriction induced by the semipermeable membrane affects the size of molecules that are allowed in the ultrafiltrate sample. As for 
microdialysis, the recovery for small molecules is close to $100 \%$, whereas in vitro recovery for albumin has been found to be $74 \%$ [57], suggesting that ultrafiltration can be used for interstitial fluid sampling. The technique has also been used for collection of tissue fluid from skin $[58,59]$ and fibrosarcomas in mice [60] using membranes with MW cutoff of $400 \mathrm{kDa}$ to allow for sampling of proteins secreted to the interstitial fluid ("secretome"). The protein concentration in the sampled fluid is, however, very low compared to that obtained with other methods $(1 / 300$ or lower for skin or $<1 / 1000$ for tumors; see section "Composition of tumor interstitial fluid" and Table 2). These results suggest that proteins are sieved off at the capillary membrane, in the tissue or at the tissue-membrane interface during ultrafiltration, and accordingly that ultrafiltration fluid does not represent interstitial fluid composition.

\section{Tissue centrifugation}

Recently, we described a centrifugation method for tumor interstitial fluid isolation [61] based on experiments having shown that tissue fluid could be isolated from cornea [62] and tail tendon $[63,64]$ by exposing tissue to increased G-force. Crucial questions are whether the isolated fluid represents undisturbed interstitial fluid and whether there is contamination with cell fluid. Cell compression during centrifugation may lead to extrusion of cellular fluid, resulting in the isolation of a mixture of interstitial and cytoplasmic fluid. This question has been addressed in a study in rats bearing chemically induced mammary carcinomas using the extracellular tracer ${ }^{51}$ Cr-ethylenediaminetetraacetic acid (EDTA) as a probe to show possible 'contamination' of cellular fluid. Addition of tumor cell fluid to the centrifuged volume should thus show up as a reduced ${ }^{51} \mathrm{Cr}$-EDTA concentration in the centrifugate relative to plasma (Figure 2). The finding of a ratio in peripheral tumor not significantly different from 1.0 for $g \leq 424$ suggested no dilution of extracellular fluid, indicating that the isolated fluid is representative for TIF provided a G-force in this range. The procedure was later found suitable for interstitial fluid isolation in other tumor models $[65,66]$.

\section{Tissue elution}

Recently, in a search for novel biomarkers, Celis et al. [67] proposed that tissue elution would be a suitable method to isolate tumor interstitial fluid. They used clean, fresh biopsies obtained from women with invasive breast cancer. Biopsies were cut into small pieces (1-3 $\mathrm{mm}^{3}$ ) that were washed carefully and placed in tubes containing phosphate-buffered saline. After incubation or elution for $1 \mathrm{~h}$ followed by centrifugation, the supernatant was collected and named tumor interstitial fluid. Later, they used the same elution method to isolate fat interstitial fluid [68]. In the tumor study, they found that the TIF contained some major serum proteins as might be expected, but that its overall protein profile was remarkably different from that of serum. Clearly, sectioning of cell-rich tumors into small pieces results in sectioning of an unknown fraction of cells and addition of cell fluid to the eluate.

\section{Composition of tumor interstitial fluid}

The functional importance of the TIF has been acknowledged in earlier studies by Jain [42], and it is therefore surprising that there has been little focus on the TIF compartment. We here briefly discuss old data and focus on new developments. In doing so, we discuss the data in light of the limitations inherent for the methods used for fluid isolation.

Gullino et al. [41,69] were the first to measure the concentration of various low molecular weight solutes, and in Table 2 we have summarized data on some characteristics of TIF. When compared to plasma and

Table 2 Composition of interstitial fluid in tumors

\begin{tabular}{|c|c|c|c|c|c|c|c|c|c|c|c|c|}
\hline \multirow[t]{2}{*}{ Tumor type } & \multirow[t]{2}{*}{ Host } & \multicolumn{3}{|c|}{ Protein, $\mathrm{mg} / \mathrm{ml}$} & \multicolumn{3}{|c|}{$\mathrm{COP}, \mathrm{mm} \mathrm{Hg}$} & \multicolumn{2}{|c|}{$\mathrm{pH}$} & \multicolumn{2}{|c|}{$\begin{array}{l}\text { Lactic acid, } \\
\mathrm{mg} / \mathrm{l}\end{array}$} & \multirow[t]{2}{*}{ Reference } \\
\hline & & TIF & Subcutis & Plasma & TIF & Subcutis & Plasma & TIF & $\begin{array}{l}\text { Plasma } \\
\text { (arterial) }\end{array}$ & TIF & Plasma & \\
\hline Carcinoma (Walker 256) & Rat & $\begin{array}{c}32 \pm \\
1\end{array}$ & $41 \pm 2$ & $48 \pm 1$ & & & & $\begin{array}{c}7.044 \\
\pm 0.044\end{array}$ & $\begin{array}{c}7.313 \pm \\
0.041\end{array}$ & $\begin{array}{c}16.1 \pm \\
1.1\end{array}$ & $\begin{array}{c}9.5 \pm \\
0.9\end{array}$ & {$[41,95]$} \\
\hline Mammary carcinoma & Mouse & 54 & & $55-60$ & & & & & & & & {$[40]$} \\
\hline Carcinoma (Walker 256) & Rat & & & & & & & $\begin{array}{c}6.98 \pm \\
0.13\end{array}$ & & 15 & 15 & {$[70]$} \\
\hline $\begin{array}{l}\text { Colon adenocarcinoma } \\
(\mathrm{LS} 174 \mathrm{~T})\end{array}$ & Mouse & & & & $\begin{array}{c}16.7 \pm \\
3.0\end{array}$ & & & & & & & {$[43]$} \\
\hline $\begin{array}{l}\text { Small cell lung carcinoma } \\
(54 \mathrm{~A})\end{array}$ & & & & & $\begin{array}{l}21.1 \pm \\
2.8\end{array}$ & $8.2 \pm 2.3$ & $\begin{array}{l}20.0 \pm \\
1.6\end{array}$ & & & & & \\
\hline $\begin{array}{l}\text { Mammary carcinoma } \\
\text { (chemically induced) }\end{array}$ & Rat & 44.7 & & 54.9 & $\begin{array}{c}16.6 \pm \\
1.0\end{array}$ & $13.8 \pm 1.0$ & $\begin{array}{l}20.5 \\
\pm 0.8\end{array}$ & & & & & {$[61]$} \\
\hline
\end{tabular}

COP: Colloid osmotic pressure, TIF: Tumor interstitial fluid. Empty cells in table: Value not determined 

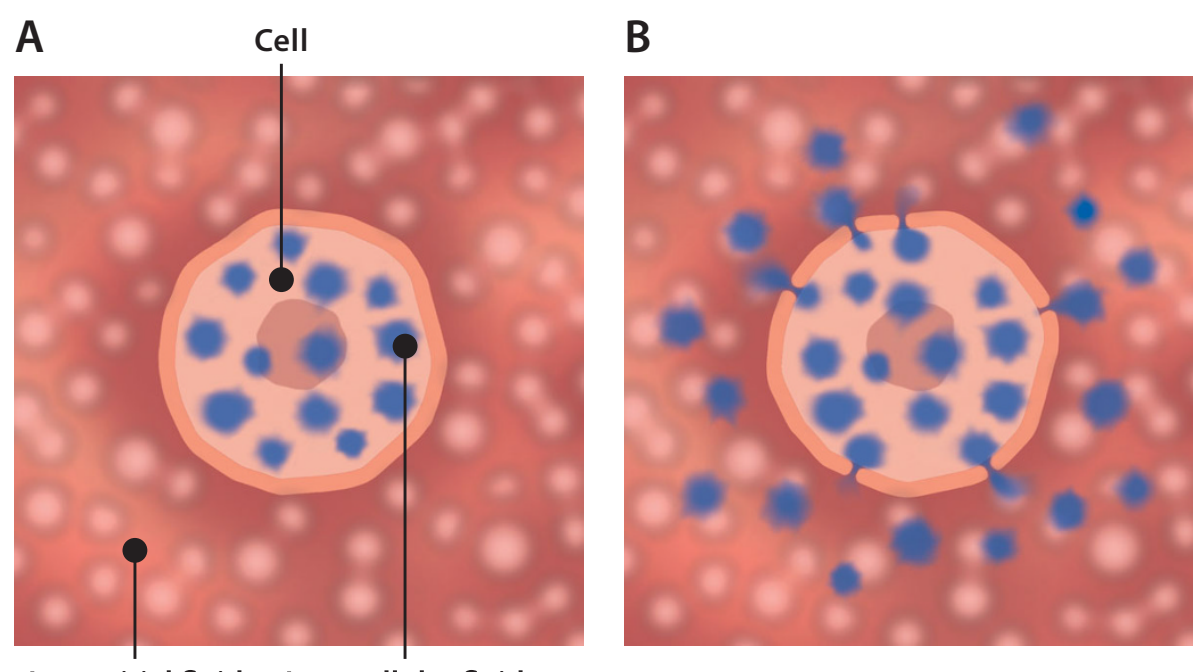

Interstitial fluid Intracellular fluid

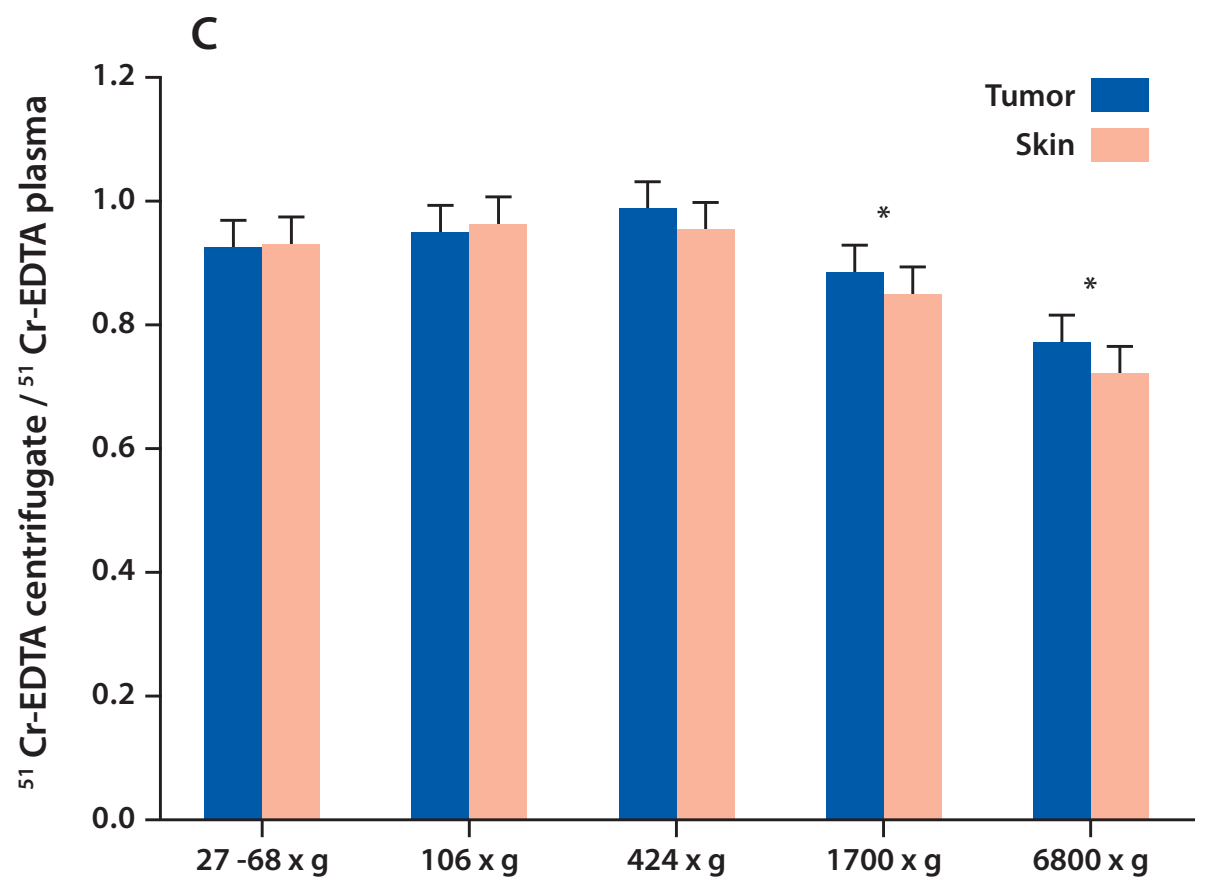

Figure 2 Determination of possible contamination of interstitial fluid. (A) A tracer that does not pass intracellularly is equilibrated in the extracellular fluid phase. (B) If undiluted interstitial fluid (IF) is isolated, the concentration in IF and plasma (P) will be equal, i.e., IF/P = 1.0. If, however, intracellular fluid (with dissolved proteins) not containing tracer is added to the interstitial fluid during the isolation process (e.g., centrifugation), the IF will become diluted and as a consequence IF/P <1.0. (C) Tissue-to-plasma distribution ratios (IF/P) of the extracellular tracer ${ }^{51}$ Cr-ethylenediaminetetraacetic acid (EDTA) as a function of G-force for interstitial fluid isolated by centrifugation from intact tumor and skin (means $\pm \mathrm{SE}$ ). For $g<424$, the IF/P ratio was not significantly different from 1.0, suggesting negligible dilution and thus contamination of IF. An $\mathrm{IF} / \mathrm{P}<1.0$ for $g>424{ }^{*} \mathrm{P}<0.05$ for tumor as well as skin) suggested contamination of IF with intracellular water and proteins (Data in Figure $2 \mathrm{C}$ modified from [61]).

subcutaneous interstitial fluid, TIF has high $\mathrm{H}^{+}, \mathrm{CO}_{2}$, and lactic acid and low glucose and $\mathrm{O}_{2}$, probably a result of tumor metabolism [42]. Of note, the $\mathrm{pH}$ of the TIF was 0.2-0.4 units lower and fell even more with increasing tumor size [70], the $\mathrm{P}_{\mathrm{CO} 2}$ was $16-39 \mathrm{mmHg}$ higher, and the concentration of bicarbonate was 4-6 mmol/l higher when compared to afferent plasma.

There has, however, been some development during recent years regarding the macromolecular composition of TIF that is of importance for our understanding of 
transcapillary fluid balance in tumors. The transcapillary fluid exchange is determined in tumors as in normal tissue by the Staling principle, i.e., by the net filtration pressure being the difference between the hydrostatic and colloid osmotic pressure acting across the capillary wall.

Whereas there are numerous studies where tumor interstitial fluid pressure has been measured and found to be elevated (for review, see [71]); in two studies only has colloid osmotic pressure (COP) been measured in TIF (Table 2). Stohrer et al. [43] determined $\mathrm{COP}_{\mathrm{TIF}}$ in four different human tumor xenografts in mice using implanted wicks. Using chronic wicks (see section "Implanted wicks" above), they found a generally higher pressure in TIF than in subcutaneous tissue. In three of the four tumor types, COP in TIF was not significantly different from plasma (or actually tended to be higher), whereas in a colon adenocarcinoma (LS174T), the COP was $82 \%$ of that in plasma and the COP in subcutaneous interstitial fluid was $41 \%$ of the plasma value. In a recent study, we measured COP in TIF isolated by centrifugation of excised chemically induced mammary carcinomas [61], and we found that the TIF/plasma COP ratio was $0.75-0.79$, again significantly higher than the corresponding subcutaneous ratio of 0.60 and close to the value for LS174T colon adenocarcinomas. The high COP observed in these two studies corresponds well to the high protein concentration relative to plasma of $0.8-1.0$ found by Sylven et al. [40], although the data from Gullino et al. [41] suggest lower COP in TIF in their model. Thus, although some caution must be expressed regarding potential contamination of intracellular and plasma proteins discussed for capillary and wick sampling above (see sections "Glass capillaries" and "Implanted wicks"), all data suggest that there is a high colloid osmotic pressure and protein concentration in TIF.

The observed protein distribution pattern in interstitial fluid may also be of interest since this pattern may have implications for the interpretation of potential biomarker candidates that are discussed in the following section. Gullino et al. [41] subjected TIF to paper electrophoresis and found an albumin-to-globulin ratio of TIF similar to that of afferent blood. A somewhat different picture was observed by Stohrer et al. [43] after separation by sodium dodecyl sulfate-gel electrophoresis. For proteins $25-75 \mathrm{kDa}$, the concentration in TIF and plasma was not significantly different, whereas for proteins with MW $<25 \mathrm{kDa}$ the concentration in TIF was on average 2.4 times higher than in plasma. As noted by Stohrer et al. [43], these smaller proteins can be breakdown products from necrotic areas and tumor-derived cell proteins as well as cellular enzymes [40]. We compared the gel chromatography elution patterns for TIF with that of plasma [61], and whereas the patterns for albumin (MW $\sim 69 \mathrm{kDa}$ ) and larger molecules were similar, there was a larger fraction of molecules eluting in the lower MW region, in agreement with data from Stohrer et al. [43] discussed above. Clearly there is a need for identification of proteins in TIF to better characterize the microenvironment and thus to understand local signaling events as well as to search for potential biomarkers.

\section{Biological implications of recent studies on interstitial fluid}

Adding to the value of identifying "new" substances in the interstitium, e.g., using proteomic approaches, it is also important to quantify known bioactive compounds in the interstitial fluid. Numerous growth factors and cytokines are associated with and sequestered in the ECM (e.g., [72-75]). Posttranslational modifications may occur in this compartment, and to be able to understand biological processes, it may be of importance to monitor biomolecules in the compartment where they are biologically active, i.e., in the interstitial fluid rather than at a gene level as elegantly shown by Garvin and Dabrosin [76]. In a mammary cancer model they demonstrated that although estradiol and the antiandrogen tamoxifen increased mRNA and intracellular VEGF protein, the secreted VEGF to the extracellular phase, and thereby angiogenesis, was decreased by the latter substance. Such observations highlight the importance of studying signaling substances in the interstitial fluid phase of the target organ and also show the importance of quantification of substances in the microenvironment.

Having demonstrated that interstitial fluid could be isolated from bone marrow in rats and humans by centrifugation [77], we then isolated bone marrow interstitial fluid (BMIF) from patients with acute myeloid leukemia (AML) at the time of diagnosis and 2-4 weeks after the start of induction therapy [78]. We found that AML-derived BMIF, but not plasma, repressed hematopoietic cell growth and that this effect was lost by successful induction treatment (Figure 3). Tumor necrosis factor $\alpha$ and adiponectin concentrations were higher in BMIF showing local production, and our experiments [78] suggested that these two cytokines had a mechanistic role in the disease process. Whereas plasma levels of these cytokines were unaffected by therapy, the levels fell significantly in BMIF in patients entering remission, showing that quantification of substances in interstitial fluid may give important information on disease progression. Two recent studies $[79,80]$ have shown the therapeutic importance of targeting syndecan-1 heparan sulfate proteoglycan in the local microenvironment and not in plasma in hematological cancers. 


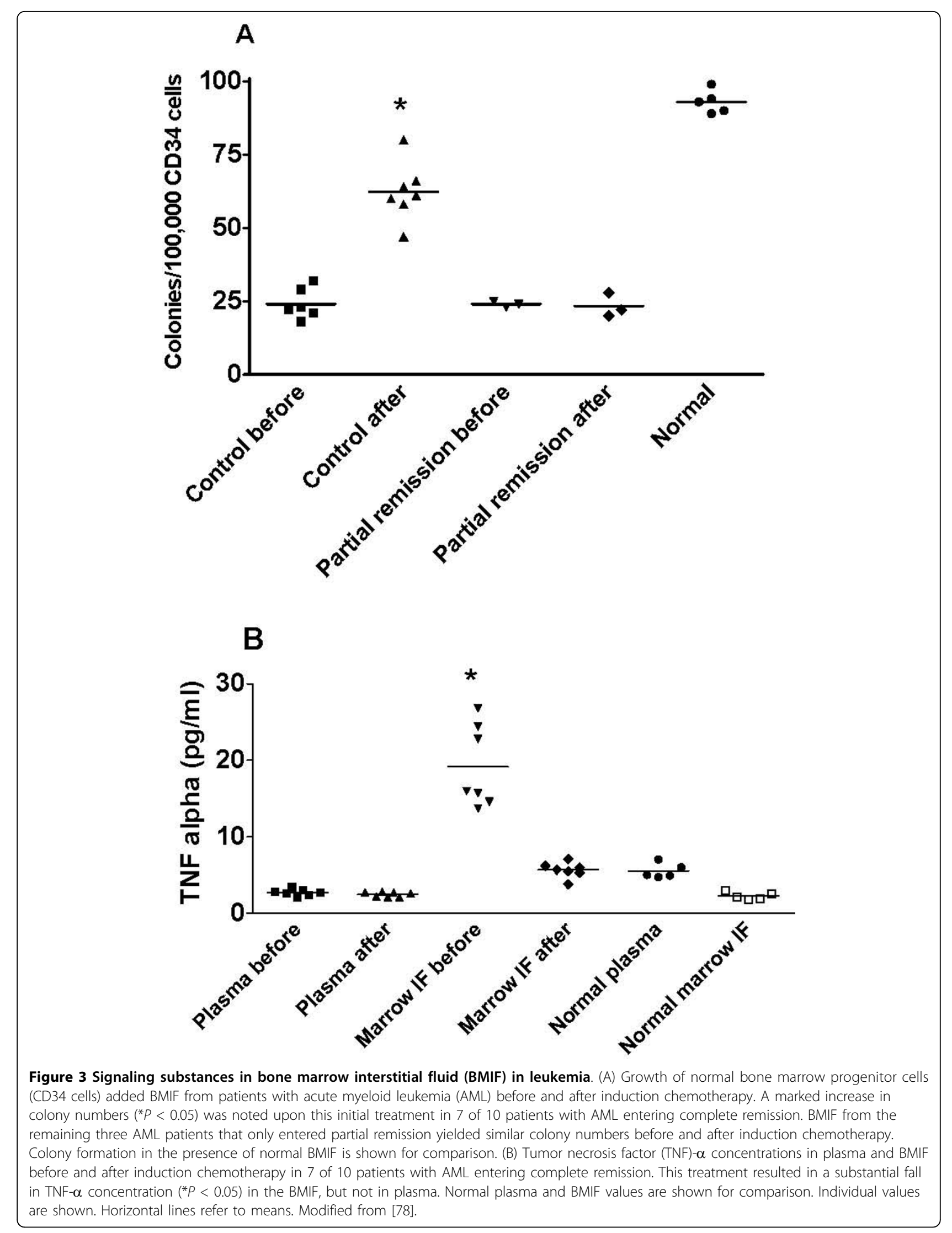




\section{The microenvironment as a potential target for identification of biomarkers}

The advances of mass spectrometry techniques combined with bioinformatics allow detection, identification and quantification of numerous peptides and proteins in biological samples (e.g. [81-86]). The emergence of these technologies and the possibility of isolating fluid deriving from a specific tissue environment offer new avenues for detection of tissue-specific biomarkers, notably for tumors. Biomarkers may be defined as molecular indicators whose presence or metabolism correlates with important disease-related processes and/or disease outcomes [87] and may be important for detection of risk, early disease and response to treatment. An attractive source for biomarkers is fluids that can be sampled noninvasively, and in addition to plasma/serum, such studies have been performed on urine, cerebrospinal fluid, bronchoalveolar lavage fluid, synovial fluid, nipple aspirate fluid, tear fluid and amnion fluid (reviewed in [88]). One general problem is the complexity of the fluids sampled and the dynamic range in the proteins sampled. This applies especially to plasma/serum, and therefore techniques have emerged to enrich and study subproteomes to reduce the complexity and to be able to detect low abundant proteins $[89,90]$. Still, even when studying subproteomes of plasma/serum, the potential biomarkers deriving from a local disease process such as solid cancer will be diluted in a substantial volume, which represents the sum of the cellular processes of the body. The chances of detecting disease-specific biomarkers will therefore be greater if the search is performed closer to the disease process, i.e., in the tissue microenvironment. Tumor cells are known to release specific substances that disrupt the tissue and elicit local responses, and it is likely that candidates can be found locally in the tumor cell secretome, i.e., specific substances secreted by tumor cells [91-94]. For this purpose it is necessary to have a technique that reflects the true interstitial fluid.

\section{Summary and perspectives}

Although substantial interest has been devoted to the ECM, the same cannot be said about the interstitial or extracellular fluid phase. Here we have focused on the interstitial fluid phase of tumors, and although the importance of this type of study in normal as well as neoplastic tissues was emphasized more than 20 years ago [42], there have been surprisingly few studies on this topic in tumors since the classical studies by Gullino et al. [41] more than 40 years ago. More recently it has been established that the colloid osmotic pressure gradient across the tumor microvascular wall is low, consistent with the findings of increased permeability of tumor vessels. With the development of new methods, local cytokine gradients between tumor and plasma have been demonstrated that may result in new insight in tumor biology. The emergence of proteomic technologies makes interstitial fluid in general, but particularly that from tumors, a very valuable source for biomarkers. As we have discussed, a major challenge in this quest is to ascertain that the source fluid derives from the interstitial fluid, but if we can, the potential of such an approach is substantial.

\section{Acknowledgements}

HW is a recipient of grants from The Research Council of Norway (project 186128/V40), the Faculty of Medicine and Dentistry and Locus on Circulatory Research, University of Bergen, Norway. Financial support was also received from the European Union 6th framework program Integrated Project "Angiotargeting" (Contract no. 504743), The Norwegian Cancer Society, The Throne Holst Foundation. RK is supported by the National Institutes of Health grants CA125550 and DK 55001, the Champalimaud Metastasis Program and the research funds of the Division of Matrix Biology at the Beth Israel Deaconess Medical Center.

\section{Author details}

${ }^{1}$ Department of Biomedicine, University of Bergen, Bergen, Norway. ${ }^{2}$ Division of Matrix Biology, Department of Medicine, Beth Israel Deaconess Medical Center and Harvard Medical School, MA, USA. ${ }^{3}$ Department of Nutrition, Institute of Basic Medical Sciences, Faculty of Medicine, University of Oslo, Oslo, Norway.

\section{Authors' contributions}

HW conceived of the study and wrote the paper, OT, POI, RK and RB participated in its design and helped to draft the manuscript. All authors read and approved the final manuscript.

\section{Competing interests}

The authors declare that they have no competing interests.

Received: 4 May 2010 Accepted: 23 July 2010 Published: 23 July 2010

\section{References}

1. Freitas I, Baronzio GF, Bono B, Griffini P, Bertone V, Sonzini N, Magrassi GR, Bonandrini L, Gerzeli G: Tumor interstitial fluid: misconsidered component of the internal milieu of a solid tumor. Anticancer Res 1997, 17:165-172.

2. Aukland K, Nicolaysen G: Interstitial fluid volume: local regulatory mechanisms. Physiol Rev 1981, 61:556-643.

3. Aukland K, Reed RK: Interstitial-lymphatic mechanisms in the control of extracellular fluid volume. Physiol Rev 1993, 73:1-78.

4. Michel C: Fluid movement through capillary walls. Handbook of Physiology The cardiovascular system Volume IV Microcirculation Bethesda, MD: American Physiological SocietyRenkin E, Michel C 1984, 375-409.

5. Michel CC, Curry FE: Microvascular permeability. Physiol Rev 1999, 79:703-761.

6. Rippe B, Haraldsson B: Transport of macromolecules across microvascular walls: the two-pore theory. Physiol Rev 1994, 74:163-219.

7. Taylor A, Granger D: Exchange of macromolecular substances across the capillary wall. Handbook of Physiology The cardiovascular system Volume IV Microcirculation Bethesda, MD: American Physiological SocietyRenkin E, Michel C 1984, 467-520.

8. Curry FR: Microvascular solute and water transport. Microcirculation 2005, 12:17-31.

9. Mehta $D$, Malik $A B$ : Signaling mechanisms regulating endothelial permeability. Physiol Rev 2006, 86:279-367.

10. Bert $J$, Pearce $\mathrm{RH}$ : The interstitium and microvascular exchange. Handbook of Physiology Sect 2: The cardiovascular system Volume IV, Microcirculation Bethesda, MD: American Physiological SocietyRenkin EM, Michel CC 1984, 521-547.

11. Comper WD, Laurent TC: Physiological function of connective tissue polysaccharides. Physiol Rev 1978, 58:255-315. 
12. Jackson RL, Busch SJ, Cardin AD: Glycosaminoglycans: molecular properties, protein interactions, and role in physiological processes. Physiol Rev 1991, 71:481-539.

13. Gelse K, Poschl E, Aigner T: Collagens: structure, function, and biosynthesis. Adv Drug Deliv Rev 2003, 55:1531-1546.

14. Kjaer M: Role of extracellular matrix in adaptation of tendon and skeletal muscle to mechanical loading. Physiol Rev 2004, 84:649-698.

15. Raman R, Sasisekharan V, Sasisekharan R: Structural insights into biological roles of protein-glycosaminoglycan interactions. Chem Biol 2005, 12:267-277.

16. Coussens LM, Werb Z: Inflammation and cancer. Nature 2002, 420:860-867.

17. Kalluri R: Basement membranes: structure, assembly and role in tumour angiogenesis. Nat Rev Cancer 2003, 3:422-433.

18. Kalluri R, Zeisberg M: Fibroblasts in cancer. Nat Rev Cancer 2006, 6:392-401.

19. Mueller MM, Fusenig NE: Friends or foes: bipolar effects of the tumour stroma in cancer. Nat Rev Cancer 2004, 4:839-849.

20. Liotta $L A$, Kohn $E C$ : The microenvironment of the tumour-host interface. Nature 2001, 411:375-379

21. Mantovani A, Allavena P, Sica A, Balkwill F: Cancer-related inflammation. Nature 2008, 454:436-444

22. Sund M, Kalluri R: Tumor stroma derived biomarkers in cancer. Cancer Metastasis Rev 2009, 28:177-183.

23. Brown LF, Guidi AJ, Schnitt SJ, Van De Water L, Iruela-Arispe ML, Yeo TK Tognazzi K, Dvorak HF: Vascular stroma formation in carcinoma in situ, invasive carcinoma, and metastatic carcinoma of the breast. Clin Cancer Res 1999, 5:1041-1056.

24. Fukumura D, Xavier R, Sugiura T, Chen Y, Park EC, Lu N, Selig M, Nielsen G, Taksir T, Jain RK, Seed B: Tumor induction of VEGF promoter activity in stromal cells. Cell 1998, 94:715-725.

25. Dvorak HF, Sioussat TM, Brown LF, Berse B, Nagy JA, Sotrel A, Manseau EJ, Van de Water L, Senger DR: Distribution of vascular permeability factor (vascular endothelial growth factor) in tumors: concentration in tumor blood vessels. J Exp Med 1991, 174:1275-1278.

26. Senger DR, Galli SJ, Dvorak AM, Perruzzi CA, Harvey VS, Dvorak HF: Tumor cells secrete a vascular permeability factor that promotes accumulation of ascites fluid. Science 1983, 219:983-985.

27. Dvorak HF: Tumors: wounds that do not heal. Similarities between tumor stroma generation and wound healing. N Engl J Med 1986, 315:1650-1659.

28. Mahfouz SM, Chevallier M, Grimaud JA: Distribution of the major connective matrix components of the stromal reaction in breast carcinoma: an immunohistochemical study. Cell Mol Biol 1987, 33:453-467.

29. Takeuchi J, Sobue M, Sato E, Shamoto M, Miura K: Variation in glycosaminoglycan components of breast tumors. Cancer Res 1976, 36:2133-2139.

30. Yeo TK, Brown L, Dvorak HF: Alterations in proteoglycan synthesis common to healing wounds and tumors. Am J Pathol 1991 138:1437-1450.

31. Ronnov-Jessen L, Petersen OW, Bissell MJ: Cellular changes involved in conversion of normal to malignant breast: importance of the stromal reaction. Physiol Rev 1996, 76:69-125.

32. Albini A, Sporn MB: The tumour microenvironment as a target for chemoprevention. Nat Rev Cancer 2007, 7:139-147.

33. Bierie B, Moses HL: Tumour microenvironment: TGF $\beta$ : the molecular Jekyll and Hyde of cancer. Nat Rev Cancer 2006, 6:506-520

34. Overall CM, Kleifeld O: Tumour microenvironment - opinion: validating matrix metalloproteinases as drug targets and anti-targets for cancer therapy. Nat Rev Cancer 2006, 6:227-239.

35. Alitalo K, Tammela T, Petrova TV: Lymphangiogenesis in development and human disease. Nature 2005, 438:946-953.

36. Thiele W, Sleeman JP: Tumor-induced lymphangiogenesis: a target for cancer therapy? J Biotechnol 2006, 124:224-241.

37. Leu AJ, Berk DA, Lymboussaki A, Alitalo K, Jain RK: Absence of functional lymphatics within a murine sarcoma: a molecular and functional evaluation. Cancer Res 2000, 60:4324-4327.

38. Stacker SA, Caesar C, Baldwin ME, Thornton GE, Williams RA, Prevo R, Jackson DG, Nishikawa S, Kubo H, Achen MG: VEGF-D promotes the metastatic spread of tumor cells via the lymphatics. Nat Med 2001, 7:186-191

39. Padera TP, Kadambi A, di Tomaso E, Carreira CM, Brown EB, Boucher Y, Choi NC, Mathisen D, Wain J, Mark EJ, Munn LL, Jain RK: Lymphatic metastasis in the absence of functional intratumor lymphatics. Science 2002, 296:1883-1886

40. Sylven B, Bois I: Protein content and enzymatic assays of interstitital fluid from some normal tissues and transplanted mouse tumors. Cancer Res 1960, 20:831-836.

41. Gullino PM, Clark SH, Grantham FH: The interstitial fluid of solid tumors. Cancer Res 1964, 24:780-798.

42. Jain RK: Transport of molecules in the tumor interstitium: a review. Cancer Res 1987, 47:3039-3051.

43. Stohrer M, Boucher $Y$, Stangassinger M, Jain RK: Oncotic pressure in solid tumors is elevated. Cancer Res 2000, 60:4251-4255.

44. Wiig H, Sibley L, DeCarlo M, Renkin EM: Sampling interstitial fluid from rat skeletal muscles by intermuscular wicks. Am J Physiol 1991, 261 : H155-H165.

45. Dabrosin C: Microdialysis: an in vivo technique for studies of growth factors in breast cancer. Front Biosci 2005, 10:1329-1335.

46. Benjamin RK, Hochberg FH, Fox E, Bungay PM, Elmquist WF, Stewart CF, Gallo JM, Collins JM, Pelletier RP, de Groot JF, Hickner RC, Cavus I, Grossman SA, Colvin OM: Review of microdialysis in brain tumors, from concept to application: first annual Carolyn Frye-Halloran symposium. Neuro Oncol 2004, 6:65-74.

47. Boschi $\mathrm{G}$, Scherrmann J: Microdialysis in mice for drug delivery research. Adv Drug Deliv Rev 2000, 45:271-281.

48. Brunner M, Muller M: Microdialysis: an in vivo approach for measuring drug delivery in oncology. Eur J Clin Pharmacol 2002, 58:227-234.

49. Chu J, Gallo JM: Application of microdialysis to characterize drug disposition in tumors. Adv Drug Deliv Rev 2000, 45:243-253.

50. Dabrosin C: Positive correlation between estradiol and vascular endothelial growth factor but not fibroblast growth factor- 2 in normal human breast tissue in vivo. Clin Cancer Res 2005, 11:8036-8041.

51. Dabrosin C, Margetts PJ, Gauldie J: Estradiol increases extracellular levels of vascular endothelial growth factor in vivo in murine mammary cancer. Int J Cancer 2003, 107:535-540.

52. Zhong H, Han B, Tourkova IL, Lokshin A, Rosenbloom A, Shurin MR, Shurin GV: Low-dose paclitaxel prior to intratumoral dendritic cell vaccine modulates intratumoral cytokine network and lung cancer growth. Clin Cancer Res 2007, 13:5455-5462.

53. Zhou Q, Gallo JM: In vivo microdialysis for PK and PD studies of anticancer drugs. AAPS J 2005, 7:E659-E667.

54. Ao X, Stenken JA: Microdialysis sampling of cytokines. Methods 2006 38:331-341.

55. Clough GF: Microdialysis of large molecules. AAPS J 2005, 7:E686-E692.

56. Leegsma-Vogt $G$, Janle E, Ash SR, Venema K, Korf J: Utilization of in vivo ultrafiltration in biomedical research and clinical applications. Life Sci 2003, 73:2005-2018.

57. Schneiderheinze JM, Hogan BL: Selective in vivo and in vitro sampling of proteins using miniature ultrafiltration sampling probes. Anal Chem 1996, 68:3758-3762.

58. Huang CM, Wang CC, Barnes S, Elmets CA: In vivo detection of secreted proteins from wounded skin using capillary ultrafiltration probes and mass spectrometric proteomics. Proteomics 2006, 6:5805-5814.

59. Huang CM, Wang CC, Kawai M, Barnes S, Elmets CA: In vivo protein sampling using capillary ultrafiltration semi-permeable hollow fiber and protein identification via mass spectrometry-based proteomics. J Chromatogr A 2006, 1109:144-151.

60. Huang CM, Ananthaswamy HN, Barnes S, Ma Y, Kawai M, Elmets CA: Mass spectrometric proteomics profiles of in vivo tumor secretomes: capillary ultrafiltration sampling of regressive tumor masses. Proteomics 2006, 6:6107-6116.

61. Wiig H, Aukland K, Tenstad O: Isolation of interstitial fluid from rat mammary tumors by a centrifugation method. Am J Physiol Heart Circ Physiol 2003, 284:H416-H424.

62. Wiig H: Cornea fluid dynamics. I: measurement of hydrostatic and colloid osmotic pressure in rabbits. Exp Eye Res 1989, 49:1015-1030.

63. Aukland K: Distribution volumes and macromolecular mobility in rat tail tendon interstitium. Am J Physiol 1991, 260:H409-H419.

64. Aukland $\mathrm{K}$, Wiig H, Tenstad O, Renkin EM: Interstitial exclusion of macromolecules studied by graded centrifugation of rat tail tendon. Am J Physiol 1997, 273:H2794-H2803.

65. Choi J, Credit K, Henderson K, Deverkadra R, He Z, Wiig H, Vanpelt H, Flessner MF: Intraperitoneal immunotherapy for metastatic ovarian 
carcinoma: Resistance of intratumoral collagen to antibody penetration Clin Cancer Res 2006, 12:1906-1912.

66. Salnikov AV, Heldin NE, Stuhr LB, Wiig H, Gerber H, Reed RK, Rubin K: Inhibition of carcinoma cell-derived VEGF reduces inflammatory characteristics in xenograft carcinoma. Int J Cancer 2006, 119:2795-2802.

67. Celis JE, Gromov P, Cabezon T, Moreira JM, Ambartsumian N, Sandelin K, Rank F, Gromova I: Proteomic characterization of the interstitial fluid perfusing the breast tumor microenvironment: a novel resource for biomarker and therapeutic target discovery. Mol Cell Proteomics 2004, 3:327-344

68. Celis JE, Moreira JM, Cabezon T, Gromov P, Friis E, Rank F, Gromova I: Identification of extracellular and intracellular signaling components of the mammary adipose tissue and its interstitial fluid in high risk breast cancer patients: toward dissecting the molecular circuitry of epithelialadipocyte stromal cell interactions. Mol Cell Proteomics 2005, 4:492-522.

69. Gullino PM: The internal milieu of tumors. Prog Exp Tumor Res 1966, 8:1-25.

70. Jain RK, Shah SA, Finney PL: Continuous noninvasive monitoring of $\mathrm{pH}$ and temperature in rat Walker 256 carcinoma during normoglycemia and hyperglycemia. J Natl Cancer Inst 1984, 73:429-436.

71. Heldin $\mathrm{CH}$, Rubin $\mathrm{K}$, Pietras $\mathrm{K}$, Ostman A: High interstitial fluid pressure: an obstacle in cancer therapy. Nat Rev Cancer 2004, 4:806-813.

72. Esko JD, Selleck SB: Order out of chaos: assembly of ligand binding sites in heparan sulfate. Annu Rev Biochem 2002, 71:435-471.

73. Ferrara N, Gerber HP, LeCouter J: The biology of VEGF and its receptors. Nat Med 2003, 9:669-676.

74. Fjeldstad K, Kolset SO: Decreasing the metastatic potential in cancers: targeting the heparan sulfate proteoglycans. Curr Drug Targets 2005, 6:665-682

75. Kadenhe-Chiweshe A, Papa J, McCrudden KW, Frischer J, Bae JO, Huang J, Fisher J, Lefkowitch JH, Feirt N, Rudge J, Holash J, Yancopoulos GD, Kandel JJ, Yamashiro DJ: Sustained VEGF blockade results in microenvironmental sequestration of VEGF by tumors and persistent VEGF receptor-2 activation. Mol Cancer Res 2008, 6:1-9.

76. Garvin S, Dabrosin C: Tamoxifen inhibits secretion of vascular endothelial growth factor in breast cancer in vivo. Cancer Res 2003, 63:8742-8748.

77. Wiig H, Berggreen E, Borge BA, Iversen PO: Demonstration of altered signaling responses in bone marrow extracellular fluid during increased hematopoiesis in rats using a centrifugation method. Am J Physiol Heart Circ Physiol 2004, 286:H2028-H2034.

78. Iversen PO, Wiig H: Tumor necrosis factor alpha and adiponectin in bone marrow interstitial fluid from patients with acute myeloid leukemia inhibit normal hematopoiesis. Clin Cancer Res 2005, 11:6793-6799.

79. Kelly T, Miao HQ, Yang Y, Navarro E, Kussie P, Huang Y, MacLeod V, Casciano J, Joseph L, Zhan F, Zangari M, Barlogie B, Shaughnessy J, Sanderson RD: High heparanase activity in multiple myeloma is associated with elevated microvessel density. Cancer Res 2003, 63:8749-8756.

80. Yang Y, MacLeod V, Dai Y, Khotskaya-Sample Y, Shriver Z, Venkataraman G, Sasisekharan R, Naggi A, Torri G, Casu B, Vlodavsky I, Suva L, Epstein J, Yaccoby S, Shaughnessy JD Jr, Barlogie B, Sanderson RD: The syndecan-1 heparan sulfate proteoglycan is a viable target for myeloma therapy. Blood 2007, 110:2041-2048

81. Aebersold R, Mann M: Mass spectrometry-based proteomics. Nature 2003, 422:198-207.

82. Hanash SM, Pitteri SJ, Faca VM: Mining the plasma proteome for cancer biomarkers. Nature 2008, 452:571-579.

83. Cravatt BF, Simon GM, Yates JR: The biological impact of massspectrometry-based proteomics. Nature 2007, 450:991-1000.

84. Qian WJ, Jacobs JM, Liu T, Camp DG, Smith RD: Advances and challenges in liquid chromatography-mass spectrometry-based proteomics profiling for clinical applications. Mol Cell Proteomics 2006, 5:1727-1744.

85. Wilm M: Quantitative proteomics in biological research. Proteomics 2009, 9:4590-4605

86. Gstaiger M, Aebersold R: Applying mass spectrometry-based proteomics to genetics, genomics and network biology. Nat Rev Genet 2009, 10:617-627.

87. Jimenez CR, Piersma C, Pham TV: High-throughput and targeted in-depth mass spectrometry-based approaches for biofluid profiling and biomarker discovery. Biomarkers in Medicine 2007, 1:541-565.
88. Hu S, Loo JA, Wong DT: Human body fluid proteome analysis. Proteomics 2006, 6:6326-6353.

89. Petricoin EF, Belluco C, Araujo RP, Liotta LA: The blood peptidome: a higher dimension of information content for cancer biomarker discovery. Nat Rev Cancer 2006, 6:961-967.

90. Veenstra TD: Global and targeted quantitative proteomics for biomarker discovery. J Chromatogr B Analyt Technol Biomed Life Sci 2007, 847:3-11.

91. Hathout Y: Approaches to the study of the cell secretome. Expert Rev Proteomics 2007, 4:239-248

92. Maurya P, Meleady P, Dowling P, Clynes M: Proteomic approaches for serum biomarker discovery in cancer. Anticancer Res 2007, 27:1247-1255.

93. Xue H, Lu B, Lai M: The cancer secretome: a reservoir of biomarkers. J Transl Med 2008, 6:52.

94. Rajcevic U, Niclou SP, Jimenez CR: Proteomics strategies for target identification and biomarker discovery in cancer. Front Biosci 2009, 14:3292-3303.

95. Gullino PM, Grantham FH, Smith SH, Haggerty AC: Modifications of the acid-base status of the internal milieu of tumors. J Natl Cancer Inst 1965, 34:857-869.

doi:10.1186/1755-1536-3-12

Cite this article as: Wiig et al: Interstitial fluid: the overlooked component of the tumor microenvironment?. Fibrogenesis \& Tissue Repair 2010 3:12.

\section{Submit your next manuscript to BioMed Central and take full advantage of:}

- Convenient online submission

- Thorough peer review

- No space constraints or color figure charges

- Immediate publication on acceptance

- Inclusion in PubMed, CAS, Scopus and Google Scholar

- Research which is freely available for redistribution

Submit your manuscript at www.biomedcentral.com/submit
Ciomed Central 